\title{
МЕТОДИКА ТЕРАПІЇ ГНІЙНО-ЗАПАЛЬНИХ ПРОЦЕСІВ У КЛІНІЧНІЙ СТОМАТОЛОГІї
}

\author{
А.Г. Олійник, І.М. Мигович, М.Я. Мартинець
}

Львівський національний медичний університет імені Данила Галицького, кафедра хірургічної та ортопедичної стоматології факультету післядипломної освіти, м. Львів, Україна,

ORCID ID: 0000-0002-8150-3341,

ORCID ID: 0000-0002-7029-4011,

ORCID ID: 0000-0002-2753-7356,

e-mail:andrew.oliynyk@gmail.com

Резюме. У зв'язку з погіршенням екологічної обстановки, збільшенням числа алергічних захворювань серед населення, залишається актуальним пошук методів лікування, що дозволяють знизити кількість лікарських препаратів. Метою дослідження стало підсилення лікувального ефекту та скорочення термінів лікування хворих гострими одонтогенними гнійно-запальними захворюваннями (гострі одонтогенні періостити, остеомієліти, в тому числі ускладнені флегмонами) шляхом застосування для антисептичної обробки запальних м'яких тканин розчину діоксиду титану в озонованій дистильованій воді. Методи: У дослідженні взяло участь 73 хворих одонтогенними поверхневими флегмонами (ОФ) одного простору (підщелепні, піджувальні, криловиднонижньощелепні) у віці 19-49 років (чоловіків - 45, жінок - 28). 3 них 39 осіб склали основну групу (ОГ), в якій місцеве лікування проводили диспергованим розчином озонованої титанізованої дистильованої води (ОТДВ), 34 - контрольну групу (КГ), в якій для місцевого лікування стосували антибактерійні мазі. Результати та обговорення: У всіх хворих одонтогенними флегмонами з ОГ після застосування ОТДВ усунення больового синдрому і припинення гноєтечі відзначалося швидше, ніж у хворих з КГ. При місцевому огляді відзначалося зниження запальних явищ. Швидше проходило також повне очищення рани і початок появи грануляцій. Відзначено зниження тривалості стаціонарного лікування.

Висновки. Використання диспергованого розчину діоксиду титану субмікронного розміру в озонованій дистильованій воді в комплексному лікуванні хворих одонтогенними флегмонами сприяє швидкому поліпшенню загального стану пацієнтів і усуненню місцевих ознак запального процесу, що дозволяє скоротити терміни лікування цих категорій хворих.

Ключові слова: гнійно-запальні процеси, диспергований розчин озонованої титанізованої дистильованої води (ОТДВ).

Вступ. Гнійно-запальні захворювання (ГЗ3) залишаються одним з найпоширеніших видів патології [1,2]. Це питання має проблемний характер і для стоматології, де також відзначається зростання захворюваності ГЗ3 $[3,4]$.

Для лікування запальних захворювань м'яких тканин використовуються різноманітні препарати загальної та місцевої дії (антибіотики, антисептики, анальгетики та ін.), які можуть призводити до звикання мікрофлори і розвитку стійкості до антибактерійних препаратів, розвитку алергічних та інших побічних реакцій, зміни імунної реактивності та неспецифічних факторів захисту $[5,6,7]$. На фоні погіршення екологічної обстановки, збільшення числа алергічних захворювань серед населення, залишається актуальним пошук методів лікування, що дозволяють знизити кількість лікарських препаратів, а у деяких випадках повністю відмовитись від їх застосування [8].

Для антисептичної обробки загальноприйнятим $\epsilon$ використання розчину хлоргекседину, який в концентрації $0,1-0,2 \%$ визнано найефективнішим антисептичним засобом $[9,10,11]$. Однак, застосування хлоргексдину протипоказано при використанні концентрацій понад $0,2 \%$, для нанесення в ділянках

зубо-щелепової системи з оголеною кістковою тканиною, при хронічних запальних процесах у м'яких тканинах зі здовженим їх загоєнням $[10,11]$. Хлоргекседин при надмірному застосуванні здатний викликати десквамацію епітеліального покриву слизової оболонки ротової порожнини. Відомі також його побічні впливи, що зумовлюють дисклорацію емалі, дентину зубів та язика, а також пригнічення смакової чутливості [12].

У зв'язку з цим, особливий інтерес представляють методи, які, поряд з локальним, мають і різносторонній вплив на організм пацієнта, і при цьому володіють мінімальними побічними ефектами. До таких методів відноситься озонотерапія.

Серед численних засобів, що застосовуються при місцевому лікуванні ГЗ3, увагу клініцистів привернула група медичних сорбентів, що забезпечують активну очисну дію на гнійну рану [14]. Головними вимогами до речовин, що використовуються як сорбенти, є: можливість вилучення великої кількості аналітів в широкому інтервалі $\mathrm{pH}$; швидка кількісна сорбція та іiі зворотність; висока відтворюваність; доступність $[15,16]$. Усім цим вимогам відповідає діоксид титану субмікронного розміру. Його основна 
перевага - велика площа поверхні та висока обмінна ємність [5, 16].

Метою дослідження стало підсилення лікувального ефекту та скорочення термінів лікування хворих гострими одонтогенними гнійно-запальними захворюваннями шляхом застосування для антисептичної обробки запальних м'яких тканин розчину діоксиду титану в озонованій дистильованій воді.

Матеріали і методи. Клінічна апробація розчину діоксиду титану в озонованій дистильованій воді проведена при комплексному лікуванні хворих гострими одонтогенними гнійно-запальними захворюваннями (гострі одонтогенні періостіти, остеомієліти, в тому числі ускладнені флегмонами). Для оцінки ефективності лікування були обрані 73 хворих одонтогенними поверхневими флегмонами (ОФ) одного простору (підщелепні, піджувальні, криловидно-нижньощелепні) у віці 19-49 років (чоловіків 45, жінок - 28).

При проведенні комплексного лікування керувалися загальновідомими принципами гнійної хірургії: розкриттям гнійно-запального вогнища шляхом пошарового розсічення тканин над ним, промиванням і адекватним дренуванням гнійної рани дренажними трубками або гумовими випускниками. Хворим основної групи (ОГ) рану полоскали диспергованим розчином озонованої титанізованої дистильованої води (ОТДВ). Озонування води досягали за допомогою озонатора GL-3188 (Сертифікат відповідності ДСТУ IEC 60335-1:2004, IDT виданий на підставі протокола випробувань НТВЦ «УкрТЕСТ» № 1783-1-2012 від 17.07.2012) з концентрацією озону 12 мг/л в режимі, встановленому інструкцією виробника. В озоновану дистильовану воду вводили порошок діоксиду титану (рутил) субмікронного розміру (d.4,230нм), чистотою 99,9+\% з розрахунку отримання концентрації 0,05\%. Його синтезували методом осадження в лабораторії кафед-ри фармакологічної, органічної та біоорганічної хімії.

Місцеве лікування хворим контрольної групи (КГ) проводили за допомогою антибактеріальних мазей. Усім хворим призначалося традиційне загальне лікування (антибіотики, десенсибілізуючі препарати та ін.).

Для оцінки динаміки запального процесу ми скористались бальною системою оцінки вираженості клінічних ознак флегмони, що включала загальні та місцеві ознаки. Градація ознак становила від 0 до 3 балів, максимальна сума балів загальних і місцевих ознак - 20 (табл. 1).

Ефективність лікування оцінювали за суб'єктивними відчуттями хворих і клінічними спостереженнями.

Статистичну обробку цифрового матеріалу проводили за допомогою комп'ютера за загальноприйнятими методами 3 використанням t-критерію Стьюдента.

Результати дослідження. У всіх хворих одонтогенними флегмонами з ОГ після застосування ОТДВ усунення больового синдрому і припинення гноєтечі відзначалося на 3-ю добу, у хворих з КГ - на 4-ту добу відповідно (табл. 2). При місцевому огляді відзначалося зниження запальних явищ.

Бальна система оцінки вираженості клінічних ознак флегмони

\begin{tabular}{|c|c|c|c|}
\hline № & \multicolumn{2}{|c|}{ Ознаки } & Бали \\
\hline \multicolumn{4}{|c|}{ Загальні } \\
\hline \multirow[t]{2}{*}{1} & \multirow[t]{2}{*}{ Загальний стан } & Середньої важкості & 1 \\
\hline & & Задовільний & 0 \\
\hline \multirow[t]{3}{*}{2} & \multirow[t]{3}{*}{ Температура тіла } & Висока (понад $38^{\circ} \mathrm{c}$ ) & 2 \\
\hline & & Субфібрильна (37-38º $)$ & 1 \\
\hline & & У межах норми & 0 \\
\hline \multirow[t]{3}{*}{3} & \multirow[t]{3}{*}{ Апетит } & Відсутній & 2 \\
\hline & & Порушений & 1 \\
\hline & & Без порушень & 0 \\
\hline \multirow[t]{3}{*}{4} & \multirow[t]{3}{*}{$\mathrm{CoH}$} & Безсоння & 2 \\
\hline & & Порушений & 1 \\
\hline & & Без порушень & 0 \\
\hline \multirow[t]{2}{*}{5} & \multirow[t]{2}{*}{ Регіонарні лімфатичні вузли } & Збільшені & 1 \\
\hline & & Не збільшені & 0 \\
\hline \multirow[t]{2}{*}{6} & \multirow[t]{2}{*}{ Шкірні покриви } & Бліді & 1 \\
\hline & & Звичного кольору & 0 \\
\hline \multicolumn{3}{|c|}{ Максимальна сума балів загальних ознак } & 9 \\
\hline
\end{tabular}




\begin{tabular}{|c|c|c|c|}
\hline \multicolumn{4}{|c|}{ Місцеві } \\
\hline \multirow[t]{2}{*}{1} & \multirow[t]{2}{*}{ Обмеження відкривання рота } & E & 1 \\
\hline & & Немає & 0 \\
\hline \multirow[t]{3}{*}{2} & \multirow[t]{3}{*}{ Інфільтрат } & Виражений & 2 \\
\hline & & Визначається & 1 \\
\hline & & Відсутній & 0 \\
\hline \multirow[t]{4}{*}{3} & \multirow[t]{4}{*}{ Наявність болю в ділянці гнійної рани } & Сильний & 3 \\
\hline & & Помірний & 2 \\
\hline & & Слабий & 1 \\
\hline & & Відсутній & 0 \\
\hline \multirow[t]{2}{*}{4} & \multirow[t]{2}{*}{ Наявність болю при ковтанні } & E & 1 \\
\hline & & Немає & 0 \\
\hline \multirow[t]{2}{*}{5} & \multirow[t]{2}{*}{ Іррадіація болю по ходу трійчастого нерва } & E & 1 \\
\hline & & Немає & 0 \\
\hline \multirow[t]{2}{*}{6} & \multirow[t]{2}{*}{ Перев’язки } & Болісні & 1 \\
\hline & & Безболісні & 0 \\
\hline \multirow[t]{3}{*}{7} & \multirow[t]{3}{*}{ Наявність запаху з гнійної рани } & Виражений & 2 \\
\hline & & Слабий & 1 \\
\hline & & Відсутній & 0 \\
\hline \multicolumn{3}{|c|}{ Максимальна сума балів місцевих ознак } & 11 \\
\hline \multicolumn{3}{|c|}{ Максимальна сума балів загальних і місцевих ознак } & 20 \\
\hline
\end{tabular}

Динаміка клінічних показників хворих одонтогенними флегмонами

\begin{tabular}{|l|c|c|}
\hline \multicolumn{1}{|c|}{ Клінічні показники } & Основна група & Контрольна група \\
\hline Усунення больового синдрому & 3-я доба & 4-та доба \\
\hline Припинення гноєтечі & 3-я доба & д-а доба \\
\hline Повне очищення рани & 6-та доба & 8 -а доба \\
\hline Початок появи грануляцій в рані & 6-та доба & 8 -а доба \\
\hline Накладення вторинних швів & 6-та доба & $15,0 \pm 0,9$ ліжко-дня \\
\hline Терміни лікування & $12,5 \pm 0,6$ ліжко-дня & \\
\hline
\end{tabular}

Повне очищення рани і початок появи грануляцій відбувалося на 6-ту і 8-му добу відповідно, після чого накладалися вторинні шви. Відзначено зниження тривалості стаціонарного лікування на 2,5 $\pm 0,7$ ліжко-дня $(\mathrm{p}<0,05)$. Побічних реакцій, скарг та ускладнень ні в одному випадку не відзначалося.

Аналогічну картину ми спостерігали і за динамікою загальних і місцевих ознак вираженості запального процесу у хворих ОФ. При цьому значення показників загальних і місцевих ознак, а також їх сумарні значення у представників ОГ та КГ на 1-у добу спостереження практично не відрізнялися між собою $(\mathrm{p}>0,05)$.

На 2-у добу відбулося зниження значень цих показників - виражене у хворих ОГ (p <0,01) і статистично недостовірне у осіб КГ ( $>>0,05)$. Між собою різниця величин цих показників була достовірною при порівнянні загальних ( $\mathrm{p}<0,05)$, місцевих ознак ( $<0,05)$, а також їх сумарного значення $(\mathrm{p}<0,01)$.
На 3-ю добу спостереження зниження значень цих показників продовжилося як у хворих ОГ (р $<$ від 0,05 до 0,001), так і КГ (р <від 0,05 до 0,01). Різниця величин цих показників між собою також була достовірною при порівнянні загальних $(\mathrm{p}<0,05)$, місцевих ознак ( $<<0,01)$, а також їх сумарного значення $(\mathrm{p}<0,01)$.

На 4-ту добу зниження значень всіх показників також було статистично достовірним у хворих ОГ ( ця величин показників ОГ і КГ була достовірною при порівнянні загальних (p <0,01), місцевих ознак (p $<0,001)$, а також їх сумарного значення $(\mathrm{p}<0,001)$.

На 6-ту добу продовжилося зниження значень всіх показників у хворих ОГ (р<від 0,05 до 0,01$)$ i КГ (p <0,05). Однак різниця величин показників ОГ i ГС на цьому етапі спостережень продовжувала залишатися статистично значущою при порівнянні зага- 
льних ( $<<0,01)$, місцевих ознак ( $<<0,01)$, а також їх сумарного значення $(\mathrm{p}<0,01)$.

На 8-му добу у осіб ОГ відбулася нормалізація показників. При цьому динаміка змін була статистично незначною ( $>>0,05)$, а зниження значень всіх показників у хворих з КГ було достовірним (p <від 0,05 до 0,01). Однак різниця величин показників ОГ і КГ на цьому етапі спостережень продовжувала залишатися статистично значущою тільки при порівнянні місцевих ознак $(\mathrm{p}<0,05)$, а також їх сумарного значення $(\mathrm{p}<0,05)$.

Таким чином, динаміка змін вираженості загальних і місцевих ознак запального процесу у хворих ОФ також підтверджувала динаміку клінічних показників.

Обговорення результатів. Озонотерапія є добрим доповненням до традиційних методів лікування в стоматології, що дозволяе знизити кількість лікарських препаратів, а у деяких випадках повністю відмовитись від їх застосування. Методики іiі проведення достатньо прості та доступні в практичній діяльності [13]. Відомо, що озонотерапія володіє імуномоделюючим, протизапальним, бактерицидним, вірусолітичним, фунгіцидним, цитостатичним, антистресовим та анальгізуючим впливом [7].

Під час зовнішнього застосування високих концентрацій газоподібного озону та озонованих розчинів проявляються його потужні окислювальні властивості, спрямовані супротив мікроорганізмів. Крім того, озон є більш ефективним у вологому середовищі, так як під час розпаду озону у воді створюється високореакційний гідроксил-радикал [9]. Озон убиває всі види бактерій, вірусів, грибів та найпростіших. При цьому, на відміну від більшості антисептиків, озон не викликає суттєвого руйнівного та подразнюючого впливу на тканини, оскільки клітини макроорганізму мають власну антиоксидантну систему захисту [8]. Встановлено, що озоновані розчини мають бактерицидні властивості при концентрації озону в розчині 12 - 20 мг/л. У цьому випадку гине до $88,1 \%$ колоній мікробних штамів, які спричиняють інфекційно-запальні процеси зубо-щелепної системи [7].

Диспергований розчин у дистильованій озонованій воді діоксиду титану субмікронного розміру забезпечує відмінну сорбцію мікроорганізмів та їхніх токсинів, продуктів розпаду тканин, токсичних метаболітів, локалізацію їх у рані та наступну елімінацію 3 вогнища запалення [9]. Деконтамінуючі речовини озонованої води представлені біокаталітично активною низькоконцентрованою сумішшю компонентів активного кисню і неорганічних метастабільних пероксидних сполук. Метастабільна суміш оксидантів в озонованому розчині $\epsilon$ найбільш ефективною з усіх відомих засобів знищення мікроорганізмів, оскільки має безліч спонтанно зреалізованих можливостей незворотнього порушення життєво важливих функцій біонолімерів мікроорганізмів на рівні реакцій передачі електронів. За механізмом біоцидної дії озонована вода подібна газовій плазмі, а продуктами ії деградації є вихідні речовини, тобто слабко мінералізована абсолютно нешкідлива вода $[19,20,13]$.
Висновки. Використання диспергованого розчину діоксиду титану субмікронного розміру в озонованій дистильованій воді в комплексному лікуванні хворих одонтогенними флегмонами і хворих з загостреним хронічним генералізованим пародонтитом сприяє швидкому поліпшенню загального стану пацієнтів і усуненню місцевих ознак запального процесу, що дозволяє скоротити терміни лікування цих категорій хворих.

Необхідно відзначити, що розчин ОТДВ дозволяє в ранні терміни нівелювати больовий синдром, забезпечити безболісність перев'язок і дезодорацію гнійного ексудату. Він ефективний і простий у використанні, не має протипоказань і не викликає побічних і алергічних реакцій.

\section{References:}

1. Bilyayeva OO, Karol IV, Filonenko HV, Kryzhevskyy YeYe. Osoblyvosti vydovoho skladu zbudnykiv hniyno-zapalnykh zakhvoryuvan myakykh tkanyn //Ukrayinskyy medychnyy chasopys. [Internet]. 2017, May. [cited 2019 May]; 3(119)-V/VI. Available at: https: //www.umj.com.ua/wp/wpsontent/uploads/2017/05/312313213.pdf? Upload

2. Viltsanyuk OA, Khutoryanskyy MO. Kharakterystyka zbudnykiv hniyno-zapalnykh protsesiv myakykh tkanyn ta pislyaoperatsiynykh hniynykh uskladnen u khvorykh zahalno-khirurhichnoho statsionaru // Kharkivska khirurhichna shkola. 2012; 2(53):84-7.

3. Adubetska AYu, Shnayder SA. Osoblyvosti perebihu ta diahnostyka hniyno-zapalnykh zakhvoryuvan shchelepno-lytsevoyi dilyanky u khvorykh na tsukrovyy diabet. Intehratyvna Antropolohiya. 2017; 2(30):33-9.

4. Lokes KP. Analiz prychyn nezadovil'nykh rezultativ likuvannya khvorykh iz hniyno-zapalnymy protsesamy shchelepnolytsevoyi dilyanky . Aktualni problemy suchasnoyi medytsyny: Visnyk ukrayinskoyi medychnoyi stomatolohichnoyi akademiyi. 2014; 4:19-21.

5. Sainuddin S, Hague R, Howson K, Clark S. New admission scoring criteria for patients with odontogenic infections: a pilot study [Electronic resource]. Br J Oral Maxillofac Surg. 2016. Available at: https://www.ncbi.nlm.nih.gov/ pubmed/27238201.

6. Matolych UD, Horhota AI, Lapovets LYe, Horhota IM. Kliniko-laboratorni aspekty syndromu endohennoyi intoksykatsiyi u khvorykh na abstsesy ta flehmony shchelepno-lytsevoyi dilyanky. Novyny stomatolohiyi. 2013; 4:16-20.

7. Barylo OS, Sklyaruk NV, Furman RL. Kompleksne likuvannya hniyno-zapalnykh zakhvoryuvan shchelepnolytsevoyi dilyanky. Visnyk morfolohiyi. 2014; 2(20):5049.

8. Oliynyk AH, Vovk YuV. Likuvannya peryimplantytu $\mathrm{z}$ vykorystannyam dysperhovanoho rozchynu $\mathrm{V}$ dystyliovaniy vodi dioksynu tytanu submikronnoho rozmiru. Novyny stomatolohiyi. 2013; 3(76):88-92.

9. Timofeyev AA. Sravnitelnaya otsenka antisepticheskikh preparatov, ispolzuyemykh dlya poloskaniya polosti rta posle dentalnoy implantatsii. Sovremennaya stomatologiya. 2013; 1:94-102.

10. Melnychuk HM, Zaverbna LV, Melnychuk AS, Kashivska RS. Medykamentozne likuvannya khvorob parodonta. Hrupy preparativ, mekhanizm yikh diyi, 
pokazannya ta protypokazannya do vykorystannya. Chastyna I. Novyny stomatolohiyi, 2013; 1(74):92-7.

11. Melnychuk HM, Zaverbna LV, Melnychuk AS, Kashivska RS. Medykamentozne likuvannya khvorob parodonta. Hrupy preparativ, mekhanizm yikh diyi, pokazannya ta protypokazannya do vykorystannya. Chastyna II. Novyny stomatolohiyi, 2013; 2(75):79-84.

12. Davtyan LL, Popovych VP, Maletska ZV, Reva DV. Dekametoksyn i khlorheksydyn na vitchyznyanomu farmatsevtychnomu rynku. Farmatsevtychnyy zhurnal. 2014; 1:28-33.

13. Oliynyk AH. Dosvid likuvannya patsiyentiv $\mathrm{z}$ peryimplantatnymy zapalnymy zminamy rozchynom dioksydu tytanu v ozonovaniy dystyliovaniy vodi. Visnyk problem biolohiyi i medytsyny. 2016; 1, Том 2 (127):256-62.

14. Sidelnikova LF, Skibitskaya YeA. Obosnovaniye i perspektivy primeneniya metodov sorbtsionnoy terapii $\mathrm{v}$ kompleksnoy profilaktike stomatologicheskikh zabolevaniy. Sovremennaya stomatologiya. 2012;2:32-4.

15. Galimov RA. Kliniko-morfologicheskoye obosnovaniye vklyucheniya sorbenta «tseloform» V kompleksnoye lecheniye bolnykh odontogennymi flegmonami. [dysertatsiia]. Kazan: Kazan. Gos. Med. Un.-t; 2012. P.36.

16. Murzina EA. Obosnovaniye primineniya enterosorbentov $\mathrm{v}$ kompleksnoy terapii khronicheskikh allergodermatozov. Mistetstvo líkuvannya. Zhurnal suchasnogo líkarya. 2013; 2/3:50-3.

17. Alyakhnovich NS, Novikov DK. Rasprostranennost, primineniye $\mathrm{i}$ patologicheskiye effekty dioksida titana. Vestnik VGMU. 2016; 2(15):7-16.

18. Shi H, Magaye R, Castranova V, Zhao J. Titanum dioxide nanoparticles: a review of current toxicological data. Part. Fibre. Toxicol. 2013, Apr.; Vol. 10: 15.

19. Yermolayeva MS Sytez ta doslidzhennya

sorbtsiynykh vlastyvostey dioksynu tytanu

submikronnoho rozmiru .Visnyk Kharkivskoho

natsionalnoho universytetu. 2010; 895. Khimiya. Vyp. 18 (41).

20. Chizhov NA UF-indutsirovannaya antibakterialnaya aktivnost tonkikh plenok dioksida titana // IV

Vserossiyskaya konferentsiya po nanomaterialam NANO -2011. 2011 mar. 01-04; Moskva, RUS.

\section{УДК 616.314-002.36:615.451.34}

\section{МЕТОДИКА ТЕРАПИИ ГНОЙНО- ВОСПАЛИТЕЛЬНЫХ ПРОЦЕССОВ В КЛИНИЧЕСКОЙ СТОМАТОЛОГИИ}

\author{
А.Г. Олийнык, И.М. Мигович, М.Я. Мартынец
}

Львовский национальный медицинский университет имени Данила Галииякого, кафедра хирургической и ортопедической стоматологии факультета последипломного образования, г. Львов, Украина,

ORCID ID: 0000-0002-8150-3341,

ORCID ID: 0000-0002-7029-4011,

ORCID ID: 0000-0002-2753-7356,

e-mail: andrew.oliynyk@gmail.com
Резюме. В связи с ухудшением экологической обстановки, увеличением числа аллергических заболеваний среди населения, остается актуальным поиск методов лечения, позволяющих снизить количество лекарственных препаратов. Целью исследования стало усиление лечебного эффекта и сокращение сроков лечения больных острыми одонтогенными гнойно-воспалительными заболеваниями (острые одонтогенные периоститы, остеомиелиты, в том числе осложненные флегмонами) путем применения для антисептической обработки воспалительных мягких тканей раствора диоксида титана в озонированной дистиллированной воде. Методы: В исследовании приняло участие 73 больных одонтогенными поверхностными флегмонами (ОФ) одного пространства (подчелюстные, поджевательные, крыловиднонижнечелюстные) в возрасте 19-49 лет (мужчин - 45, женщин - 28). Из них 39 человек составили основную группу (ОГ), в которой местное лечение проводили диспергированным раствором озонированной титанизованой дистиллированной воды (ОТДВ), 34 - контрольную группу (КГ), где для местного лечения использовали антибактериальные мази. Результаты и обсуждение: У всех больных одонтогенными флегмонами с ОГ после применения ОТДВ, устранения болевого синдрома прекращение гноетечения отмечалось быстрее, чем у больных с КГ. При местном осмотре отмечалось снижение воспалительных явлений. Скорее проходило также полное очищение раны и начало появления грануляций. Отмечено снижение продолжительности стационарного лечения.

Выводы: Использование диспергированного раствора диоксида титана субмикронного размера в озонированной дистиллированной воде в комплексном лечении больных одонтогенными флегмонами способствует быстрому улучшению общего состояния пациентов и устранению местных признаков воспалительного процесса, что позволяет сократить сроки лечения данных категорий больных.

Ключевые слова: гнойно-воспалительные процессы, диспергированный раствор озонированной титанизированной дистиллированной воды (ОТДВ).

\section{UDC 616.314-002.36:615.451.34

METHOD OF THERAPY OF PURULENT-
INFLAMMATORY PROCESSES IN CLINICAL
DENTISTRY

A.H. Oliinyk, I.M. Mygovych, M.Ya. Martynets

Danylo Halytskyi Lviv National Medical University, Department of Surgical and Prosthetic Dentistry Faculty of Continuing Education for Physicians, Lviv, Ukraine, ORCID ID: 0000-0002-8150-3341,

ORCID ID: 0000-0002-7029-4011,

ORCID ID: 0000-0002-2753-7356,

e-mail: andrew.oliynyk@gmail.com

Abstract. Protocol treatment of purulentinflammatory processes includes local antibacterial ther- 
apy, antibiotic therapy, and surgical treatment. Important and relevant is the study and further development of issues related to the prevention and treatment of primary and developed inflammatory processes of soft tissues. And in those cases when it is impossible to resort to antibiotic therapy, in particular during pregnancy or intolerance to antibiotics, and the local use of antiseptics exposes adverse effect, the search for treatment methods that reduce the number of drugs, and in some cases completely refuse from their application. The solution of chlorhexidine (concentration of $0.1-0.2 \%$ ) considered the most effective mean of antiseptic treatment. However, the use of chlorhexidine has a lot of contraindications and complications. According to our research bactericidal capacity of ozonated distilled water is comparable with $0.2 \%$ chlorhexidine solution. The ozone therapy has several advantages: no systemic effects on the body, no flora resistance to ozone appears lack of ozone allergenicity.

The local detoxification sorbents for the topical treatment of inflammatory diseases have become used in recent years increasingly. Especially promising material for adsorbents is titanium dioxide, which is characterized by a large surface area and high exchange capacity.

So, we have offered use the titanium dioxide solution in ozonated distilled water for antiseptic treatment of purulent-inflammatory processes (PIP).

The purpose of the study was to increase the therapeutic effect and reduce the treatment timing of patients with acute odontogenic purulent-inflammatory diseases (acute odontogenic periostitis, osteomyelitis, including complicated phlegmons) using antiseptic dressing of inflammatory soft tissues with a solution of titanium dioxide in ozonized distilled water.
Methods. Seventy-three patients (men - 45, women - 28) aged a from 19 to 49 yrs. with odontogenic superficial phlegmon (OP) of one area (submandibular, sublingual, pterygomandibular) were examined. Thirtynine persons were in the main group (MG), and were treated with dispersed solution of ozonized tetanized distilled water (OTDW), 34 person were in the control group (CG) and treated with antibacterial ointments for local treatment. Medical schemes have included, in addition to antiseptic treatment the local and general antibiotic therapy and surgery treatment.

Results and discussion. The positive dynamics of purulent-inflammatory processes indicators was observed after treatment in all patients. But for sure the best results were obtained using developed by us techniques. In all patients with odontogenic phlegmons from $\mathrm{MG}$ after the use of OTDW elimination of pain syndrome and elimination of pain syndrome was noted faster than in patients of CG. At local examination there was a decrease in inflammatory events. Rarely, there was a complete cleansing of the wound and the onset of granulation. Decreased duration of inpatient treatment.

Conclusions. The use of a dispersed solution of titanium dioxide of submicron size in ozonized distilled water in the complex treatment of patients with odontogenic phlegmons promotes rapid improvement of the general condition of patients and elimination of local signs of the inflammatory process, which reduces the timing of treatment for these categories of patients.

Keywords: purulent-inflammatory processes, dispersed solution of ozonized tetanized distilled water (OTDW).

Стаття надійшла в редакцію14.05.2019 р. 